Research Paper

\title{
Identification and Functional Analysis of a Novel Tryptophyllin Peptide from the Skin of the Red-eye Leaf Frog, Agalychnis callidryas
}

\author{
Ran Wang ${ }^{1,2}$, Yu Zhou ${ }^{2,3}$, Tianbao Chen², Mei Zhou'2, Lei Wang'2, Chris Shaw ${ }^{2}$ \\ 1. Tianjin Key Laboratory on Technologies Enabling Development of Clinical Therapeutics and Diagnostics, School of Pharmacy. Tianjin \\ Medical University, Tianjin 300070, China \\ 2. School of Pharmacy, Medical Biology Centre, Queen's University, Belfast BT9 7BL, Northern Ireland, UK \\ 3. School of Biomedical Science and Institute of Molecular Medicine, Huaqiao University, Xiamen 361021, Fujian, China
}

$\square$ Corresponding author: Ran Wang. Tianjin Key Laboratory on Technologies Enabling Development of Clinical Therapeutics and Diagnostics, School of Pharmacy, Tianjin Medical University, Tianjin 300070, China. Email: wangran@tijmu.edu.cn, Tel: 086-022-83336658

(c) Ivyspring International Publisher. This is an open-access article distributed under the terms of the Creative Commons License (http://creativecommons.org/ licenses/by-nc-nd/3.0/). Reproduction is permitted for personal, noncommercial use, provided that the article is in whole, unmodified, and properly cited.

Received: 2014.07.18; Accepted: 2014.11.24; Published: 2015.01.05

\begin{abstract}
Amphibian skin has proved repeatedly to be a largely untapped source of bioactive peptides and this is especially true of members of the Phyllomedusinae subfamily of frogs native to South and Central America. Tryptophyllins are a group of peptides mainly found in the skin of members of this genus. In this study, a novel tryptophyllin (TPH) type 3 peptide, named AcT-3, has been isolated and structurally-characterised from the skin secretion and lyophilised skin extract of the red-eye leaf frog, Agalychnis callidryas. The peptide was identified in and purified from the skin secretion by reverse-phase HPLC. MALDI-TOF mass spectrometry and MS/MS fragmentation sequencing established its primary structure as: pGlu-Gly-Lys-Pro-Tyr-Trp-Pro-Pro-Pro-PheLeu-Pro-Glu, with a non-protonated molecular mass of 1538.19Da. The mature peptide possessed the canonical $\mathrm{N}$-terminal pGlu residue that arises from post-translational modification of a $\mathrm{Gln}$ residue. The deduced open-reading frame consisted of 63 amino acid residues encoding a highly-conserved signal peptide of approximately 22 amino acid residues, an intervening acidic spacer peptide domain, a single AcT-3 encoding domain and a $C$ terminal processing site. $A$ synthetic replicate of AcT-3 was found to antagonise the effect of BK on rat tail artery smooth muscle and to contract the intestinal smooth muscle preparations. It was also found that AcT-3 could dose-dependently inhibit the proliferation of human prostate cancer cell lines after $72 \mathrm{~h}$ incubation.
\end{abstract}

Key words: Agalychnis callidryas, proline-rich peptide, bradykinin antagonist, anticancer effect, myotropic activities

\section{Introduction}

Amphibians are one of the most widely-distributed vertebrate groups in the world, ranging from inside the Arctic Circle in the North to southern Chile and the Patagonian grasslands of southern Argentina [1]. The ability of amphibians to survive in such a broad diversity of habitat types is closely-related to their highly-adapted skins, which are highly-permeable to water and fulfilled many different morphological, physiological and biochemical functions [2]. Skin secretions of the dorsal glands of amphibians provide rich chemical arsenals of host-defence compounds that are not just confined to acting in the animal's defence system against microorganisms and predators, but are also involved in the regulation of dermal physiological actions [3]. There are two major types of glands in the amphibian skin, mucous and granular glands. Mucous glands secrete a transparent mucus secretion that helps to keep the 
skin moist and prevents mechanical damage to the delicate skin [4]. Granular glands produce a secretion containing various chemical compounds including peptides, alkaloids, biogenic amines and steroids [5, 3].

The peptides discovered in frog skin secretions exhibit a wide range of biological activities, such as antimicrobial, anti-viral, anti-tumour, insulin-releasing, analgesic, vasodilatation and immunomodulatory properties [6-10]. These peptides are potent resources for drug development. There are two extensively-used procedures for isolating frog skin peptides. The first, carried out in the early research years, involves killing frogs and extracting their dried excised skins with an organic solvent, such as methanol [11]. The second and more modern and ethical method, collects the frog skin secretions directly from the skin surface following stimulation of their release by a pharmacological mediator (such as adrenaline) or by non-invasive electrical shock to the animal [12]. After secretion acquisition, the compounds within are isolated by ion-exchange chromatography or reversed-phase high performance liquid chromatography. The separated bioactive peptides can then be assayed with a battery of bioassays, such as pharmacological assay, bactericidal assay, anti-cancer assay, insulin-releasing assay etc. [5].

The subfamily of South and Central American leaf frogs, the Phyllomedusinae, contains three well-known genera, Phyllomedusa, Agalychnis and Pachymedusa. Phyllomedusine species contain huge amounts of diverse biologically-active peptides that include both neuropeptide analogues with pharmacological activity and an abundance of several different classes of broad-spectrum antimicrobial peptides. Erspamer once described the skins of members of the Phyllomedusinae frog sub-family as "huge storehouses of bioactive peptides" [13]. These active peptides are generally divided into eight distinct families: Caeruleins-the representative peptide from this family being phyllocaerulein from $P$. sauvagei, this peptide family exhibits a spectrum of activity similar to those of the mammalian intestinal hormones gastrin and cholecystokinin [14]. Bradykinins-a large number of bradykinins and phyllokinins have been found in the skin secretion of Phyllomedusa hypochondrialis-[Val $]_{1}$, [Thr] ${ }_{6}$-bradykinyl-Gln, Ser had biological activity in cell cultures expressing the human bradykinin $\mathrm{B}_{2}$ receptor and in guinea pig ileum preparations [15]. Tachykinins-these neuropeptide analogues have high affinities for the mammalian tachykinin receptor subtypes P and K, and have been found in Agalychnis callidryas and P. bicolor [16]. Bombesins-while canonical bombesin is lacking in Phyllomedusa skin, its structural homologue, phyllolitorin, has been found in P. sauvagei, P. rohdei and P. burmeisteri skin [13]. Tryptophyllins-to date, more than $90 \%$ of the representatives of this type of peptide have been reported from phyllomedusine skin [17-19]. Sauvagine-this peptide, with forty amino acid residues, was isolated from the skin of $P$. sauvagei. Sauvagine possesses a number of biological activities including hypotension, antidiuretic, hyperglycaemic and the effects on the anterior pituitary [13]. Dermorphins-these are selective opioid-receptor active peptides isolated from the skins of $P$. sauvagei and $P$. rohdei [13]. Dermaseptins-these have been reported from the skins of all phyllomedusines studied to date and these antimicrobial peptides have been shown to be effective killers of Gram-negative and Gram-positive bacteria and some fungi [20].

Agalychnis callidryas is a widespread Central American leaf frog species belonging to the Phyllomedusinae subfamily. A. callidryas is one of the world's most beautifully-coloured amphibians and is distributed from Mexico to Panama, with an isolated report from the Cartagena Botanic Gardens in Colombia. This species inhabits humid forests, primarily in lowlands and sometimes on premontane slopes up to $1250 \mathrm{~m}$ [21]. Recent studies have shown that the peptides isolated from the skin of $A$. callidryas exhibited a wide-spectrum of biological functions [22].

Here, the isolation and structural elucidation of a novel tryptophyllin type-3 peptide (named AcT-3) from the red-eyed leaf frog, Agalychnis callidryas, utilising a mass spectrometric and 'shotgun' cDNA sequencing, is described. The peptide was subsequently chemically-synthesised successfully using a PS3 solid-phase synthesiser and bioassays with this synthetic replicate have shown that it is a non-competitive inhibitor of the effect of bradykinin on rat tail artery and a constrictor on rat small intestinal smooth muscle preparations. AcT-3 also has an anti-proliferative effect on several human prostate cancer cell lines.

\section{Materials and methods}

\section{Acquisition of skin secretions}

Adult red-eye leaf frogs, Agalychnis callidryas, were obtained from commercial sources. The frogs (both sexes, snout-to-vent length $4-6 \mathrm{~cm}$ ) were maintained in a purpose-designed terrarium under a 12h/12h light/dark cycle and were fed multivitamin-loaded crickets every two days. Animals were kept under these conditions for at least 3 months prior to experimentation. Skin secretions were obtained from the dorsal skin by transdermal electrical stimulation (6v DC, $4 \mathrm{~ms}$ pulse width, 50HZ) through platinum electrodes for two periods of $15 \mathrm{~s}$ duration. The skin secretions were washed from the skin with de- 
ionised water, snap-frozen in liquid nitrogen, lyophilised and stored at $-20^{\circ} \mathrm{C}$ prior to analysis.

\section{Construction of a cDNA library from dried skin and subsequent "shotgun" cloning}

Pieces from four frog skins (total $56 \mathrm{mg}$ dry weight) were chopped into small pieces $\left(1-2 \mathrm{~mm}^{2}\right)$ and transfered into $1 \mathrm{~mL}$ of cell lysis solution at $4^{\circ} \mathrm{C}$ for $2 \mathrm{~h}$. Polyadenylated mRNA was isolated using magnetic oligo-dT beads as described by the manufacturer (Dynal Biotech, UK) and reverse-transcribed. Standard reverse transcriptase-PCR methods were used to synthesise the first-strand cDNA and this was carried out by using a SMART RACE cDNA Amplification Kit (BD CLONTECH, UK). RACE PCR was used to amplify sequences between a single previously characterised region in the cDNA and an anchor sequence that was coupled to the $5^{\prime}$ or the $3^{\prime}$ end. Briefly, the 3'-RACE reactions employed an NUP primer (supplied with the kit) and a degenerate sense primer (S1: 5'-ACTTTCYGAWTTRYAAGMSCARABATG-3') that was designed to a highly-conserved domain of the 5 -untranslated region of previously characterised skin peptide-encoding cDNAs from Phyllomedusa species. The PCR cycling procedure was set as follows: Initial denaturation step: $60 \mathrm{~s}$ at $94^{\circ} \mathrm{C} ; 35$ cycles: denaturation $30 \mathrm{~s}$ at $94^{\circ} \mathrm{C}$; primer annealing for $30 \mathrm{~s}$ at $58^{\circ} \mathrm{C}$; extension for $180 \mathrm{~s}$ at $72^{\circ} \mathrm{C}$. PCR products were purified, cloned using a pGEM-T vector system (Promega Corporation, UK) and then sequenced by ABI 3100 automated sequencer. All putative biological peptide homologue structures deduced from cDNA clones were subjected to bioinformatic analysis using the BLAST program available on-line through the National Center for Biotechnology Information (NCBI), USA.

\section{Peptidomic analysis of defensive skin secretion}

For the purpose of isolating the functional peptides from frog skin secretions, ten milligrams of lyophilised pooled skin secretion of Agalychnis callidryas were dissolved in $1 \mathrm{~mL}$ of $0.05 \%$ (v/v) TFA and clarified of microparticulates by centrifugation $(1500 \times g)$. The clear supernatant was decanted and pumped directly onto a reverse phase HPLC column and subjected to LC/MS using a gradient formed from $0.05 / 99.5 \quad(\mathrm{v} / \mathrm{v}) \quad \mathrm{TFA} /$ water to $0.05 / 19.95 / 80.0$ (v/v/v) TFA/water/acetonitrile in $240 \mathrm{~min}$ at a flow rate of $1 \mathrm{~mL} / \mathrm{min}$. The sample was collected in one minute interval and each peak was included in one fraction or more fractions. A Thermoquest gradient reversed phase HPLC system, fitted with an analytical column (Phenomenex C-5, UK). The flow of effluent from the column was split, with $10 \%$ entering the mass spectrometer source and $90 \%$ was collected us- ing an automated fraction collector. All the fractions were subjected to MALDI-TOF mass spectrometry on a linear TOF Voyager-DE mass spectrometer (perceptive Biosystems, USA) in order to determine the $\mathrm{m} / \mathrm{z}$ values of the contents of each fraction. Then the peptide with mass coincident with the putative bioactive peptide, as deduced from cloned precursor cDNAs, was subject to structural analysis by using MS/MS fragmentation sequencing on a Solarix FT-ICR-MS (Bruker Daltonics, USA).

\section{Synthesis of AcT-3}

AcT-3 was synthesized by solid-phase peptide synthesis methodology using a PS3 Automated Solid Phase Peptide synthesizer (Protein Technologies Inc., USA). Following deprotection and cleavage from the resin, the peptide was purified by reverse-phase HPLC. The purity and the structure of the final product were monitored by MALDI-TOF MS and Solarix FT-ICR-MS.

\section{Pharmacological characterization of AcT-3}

Male albino Wistar rats (200-350g) were euthanised by carbon dioxide asphyxiation followed by cervical dislocation. The rat tail arterial smooth muscle was prepared and bathed in ice-cold 95\% $\mathrm{O}_{2} / 5 \%$ $\mathrm{CO}_{2}$ oxygenated Krebs' solution $(\mathrm{NaCl} 118 \mathrm{mM}, \mathrm{KCl}$ $4.7 \mathrm{mM}, \mathrm{NaHCO}_{3} 25 \mathrm{mM}, \mathrm{NaH}_{2} \mathrm{PO}_{4} 1.15 \mathrm{mM} \mathrm{CaCl}$ $2.5 \mathrm{mM}, \mathrm{MgCl}_{2} 1.1 \mathrm{mM}$, glucose $\left.5.6 \mathrm{mM}\right)$. Muscle strips, 2-6mm length, were dissected from rat tail artery and connected to a triangular hook which was attached to a thread. The smooth muscle preparations were inserted onto the tension transducer in $37^{\circ} \mathrm{C}$ oxygenated Krebs' solution environment. A tension of $0.5 \mathrm{~g}$ was applied to vessel preparations. The smooth muscle was pre-treated with phenylephrine $\left(1 \times 10^{-5} \mathrm{M}\right)$ for 10 min to achieve constriction plateaux after equilibration, then separate dose-response curves were constructed for BK and the novel peptide using concentrations of both peptides in the range of $1 \times 10^{-11}$ to $1 \times 10^{-5} \mathrm{M}$. The potential BK inhibitory property of the novel peptide was measured by prior addition of AcT-3 $\left(1 \times 10^{-6} \mathrm{M}\right)$ to a subsequent dose-response study with BK $\left(1 \times 10^{-11} \mathrm{M}\right.$ to $\left.1 \times 10^{-5} \mathrm{M}\right)$. Changes in tension of the tail artery smooth muscle preparations were recorded and amplified through pressure transducers connected to a PowerLab System.

For rat small intestinal smooth muscle preparations, $1 \mathrm{~cm}$ segments of small intestinal were cut and placed onto the force transducer. The muscle segments were exposed to gradually increments of resting tension until it reached $0.5 \mathrm{~g}$. The contracting muscle preparations were allowed to stabilize for 20 min before the application of peptides. The small intestinal smooth muscle preparations were exposed to 
peptides in the concentration range of $1 \times 10^{-5} \mathrm{M}$ to $1 \times 10^{-11} \mathrm{M}$, and relative changes in tension were recorded. Six replicates for each experimental data point were performed.

\section{Determination of inhibitory activity on pros- tate cancer cell lines}

The inhibitory activity of AcT-3 on three different prostate cancer lines was measured by MTT assay. Briefly, PC3, LNCaP and DU145 cells were seeded into 96-well plates at a density of 5,000 cells per well and then placed into the cell incubator. On next day, the culture medium was refreshed with the same value of serum-free RPMI 1640 medium. After $24 \mathrm{~h}$, the test concentrations from $1 \mu \mathrm{M}$ to $100 \mu \mathrm{M}$ of AcT-3 solutions were added to replace the culture medium. Paclitaxel $(1 \mu \mathrm{M})$ was used as a positive control to compare the anti-proliferative effect of peptide. $20 \mu \mathrm{L}$ of MTT was added to each sample after 24,48 and $72 \mathrm{~h}$ treatment. Four hours later, the absorbance of samples (A550) was measured by microplate spectrophotometer (BIO-RAD iMark, USA). Experiments were repeated three times in six replicates.

\section{Cell Death ELISA}

Cell Death ELISA is an enzyme-linked immunoassay used for quantification of histone-complex DNA fragments out of the cytoplasm of cells after the induction of apoptosis or when released from necrotic cells, which is also used for distinguishing the two cell death mechanisms of necrosis and apoptosis. Here, this assay was performed to distinguish the anticancer mechanism of AcT-3 by using a Cell Death Detection ELISA $^{\text {PLUS Kit }}$ (Roche, Germany). Briefly, 100 $\mu \mathrm{L}$ of Prostate cancer cells (PC3/DU145/LnCap) suspension were seeded into 96-well plates. After $24 \mathrm{~h}$, a range of concentrations of AcT-3 were added to the cells after removing the old medium. After further $4 \mathrm{~h}$ incubation, $50 \mu \mathrm{L}$ of the supernatant in each well was collected and stored at $4^{\circ} \mathrm{C}$. The plate was further incubated for $16 \mathrm{~h}$ and then centrifuged to remove the supernatant. The cell pellet was resuspended in $200 \mu \mathrm{L}$ lysis buffer and $20 \mu \mathrm{L}$ of cell lysate with $80 \mu \mathrm{l}$ immunoreagent were added into the streptavidin-coated microplate and incubated for $2 \mathrm{~h}$ on an MP shaker. Then, $100 \mu \mathrm{L}$ of substrate solution was added to microplate which was washed by incubation buffer and the plate was shaken at 100rpm for 10-20min until the colour of solution became green or dark green. At last, $100 \mu \mathrm{L}$ of ABTS stop solution was added to stop the reactions. The amount of colour product was measured using the microplate spectrophotometer.

\section{Safety evaluation of AcT-3 by haemolytic assay}

The fresh horse blood was centrifuged at $120 \times \mathrm{g}$ for $5 \mathrm{~min}$ at room temperature with the cell pellet be- ing washed three times in PBS solution until the supernatant was clear and then resuspended in PBS buffer to give a final cell concentration of $2 \%$. A range of concentrations of peptides were dissolved in PBS and added into $2 \mathrm{~mL}$ of red blood cell suspension then incubated at $37^{\circ} \mathrm{C}$ for $2 \mathrm{~h}$. $100 \mu \mathrm{L}$ of the supernatants was transferred into the 96-well plate to measure the haemolytic activity. The plate was read on an ELISA reader BIO-RAD iMark, USA) at A550.

\section{Results}

\section{Molecular cloning of AcT-3 precursor- encoding cDNA from the library}

From the Agalychnis callidryas skin extract-derived cDNA library, a novel tryptophyllin peptide (named AcT-3) precursor-encoding cDNA was consistently and cloned repeatedly for six times. The average size of the DNA inserts is about $300 \mathrm{bp}$ length. The precursor-encoding cDNA contained an open reading frame of 63 amino acid residues. The putative signal peptide was typically followed by a domain rich in acidic amino residues and containing classical processing sites (-R-R-) (Fig. 1A). Mature AcT-3 exhibited a high degree of primarily structural similarity with the homologue, PhT-3, from the skin of the orange-legged leaf frog, Phyllomedusa hypochondrialis, showing 73\% sequence identity (Fig. 1B). Their open-reading frames both consisted of 63 amino acid residues. Such similarity between AcT-3 and PhT-3 indicates that they belong to the same peptide family and probably have arisen from a common ancestral gene.

\section{Isolation and characterisation of the novel peptide, AcT-3}

The proposed putative tridecapeptide, AcT-3, was identified following reverse-phase HPLC fractionation of Agalychnis callidryas skin secretion (Fig. 2A) at the elution time of 33 mintues. MALDI-TOF analysis of this fraction, indicated a single peptide with an $\mathrm{m} / \mathrm{z}$ of 1538.19 and a high degree of purity $>80 \%$ (Fig. 2B). MS/MS fragmentation sequencing of this doubly charged ion (m/z 796.88) (Fig. 3A), produced two connective sequence: $p E G K P Y W P$ and WPPPFLP (Fig. 3B). Therefore, the primary structure of the peptide was established by a combination of molecular cloning and mass spectrometry as: pEGKPYWPPPFLPE. The mature peptide showed the N-terminal pGlu formation from Gln after post-translational modification. This peptide was named, AcT-3, based on its sequence similarity to tryptophyllin-3 peptides, which includes tridecapeptides and which possess a conserved internal -Pro-Pro-Pro-Ile-Tyr-Pro- motif [20]. 
Following obtaining the unequivocal structure, AcT-3 was successfully synthesised by using a PS3 solid phase peptide systhesier and purified using reverse phase HPLC to $>95 \%$ purity.

\section{Pharmacological effects of AcT-3 on rat smooth muscle preparations}

The synthetic AcT-3 induced a slight constriction of rat tail artery smooth muscle preparations with an EC50 value of $3.2 \times 10^{-9} \mathrm{M}$. BK was proven to induce rat tail artery smooth muscle relaxation in a previous report [24]. Here, BK was found to significantly relax rat tail artery smooth muscle preparations with an $\mathrm{EC}_{50}$ of $12.1 \times 10^{-6} \mathrm{M}$ (Fig. $\left.4 \mathrm{~A}\right)$. The optimal relaxation was noted at $10^{-6} \mathrm{M}$, with a relaxation magnitude of $59.48 \% \pm 1.43 \%$. Pre-incubation of rat tail artery smooth muscle with $1 \times 10^{-6} \mathrm{M}$ AcT-3 (the most effective concentration) reduced artery relaxation induced by $\mathrm{BK}$ (Fig. 4B). The maximal relaxation induced by $1 \times 10^{-6} \mathrm{M}$ BK was reduced to $12.8 \% \pm 0.11$, which was almost an eighty percent decrease compared to when the smooth muscle was treated with BK alone.

Application of the synthetic AcT-3 peptide to rat small intestinal in the concentration range of $1 \times 10^{-11}$ to $1 \times 10^{-5} \mathrm{M}$, confirmed it has the contracting effect on this tissue with $\mathrm{EC}_{50}$ value of $2.2 \times 10^{-8} \mathrm{M}$ (Fig.4C). The optimal contraction was at $1 \times 10^{-6} \mathrm{M}$, with a contracting magnitude of $40.28 \% \pm 4.39 \%$. Thus it can be seen, although AcT-3 showed pharmacological effects on both rat tail artery and small intestinal smooth muscle preparations, but the effects are totally different.

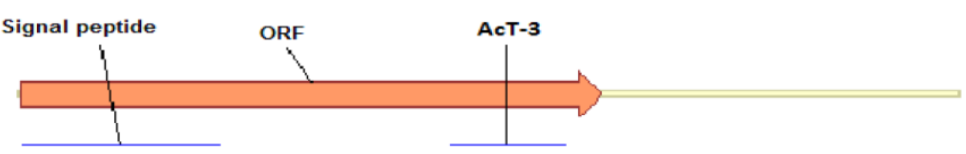

AcT-3

$300 \mathrm{bp}$

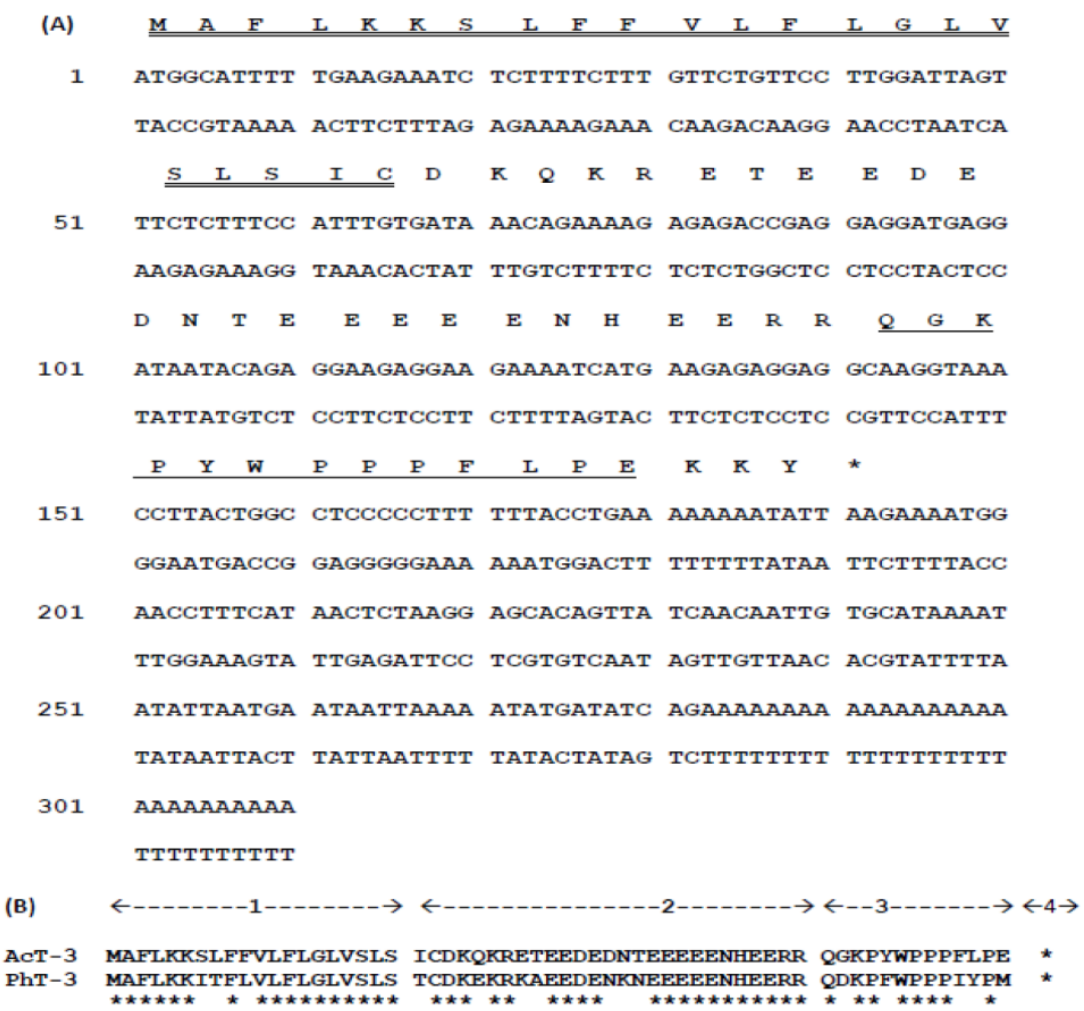

Figure 1. (A) Nucleotide sequence of frog skin-derived cDNA encoding the biosynthetic precursor of AcT-3. The putative signal peptide marked with double-underline, mature peptide marked with single-underline and stop codon (asterisk) is indicated. (B) Alignments of open-reading frame amino acid sequences of AcT-3 and PhT-3. The main structure of the precursors is indicated. (1) Putative signal peptide. (2) Acidic spacer peptide. (3) Mature peptide. (4) C-terminal processing site. Conserved residues are indicated by asterisks. 

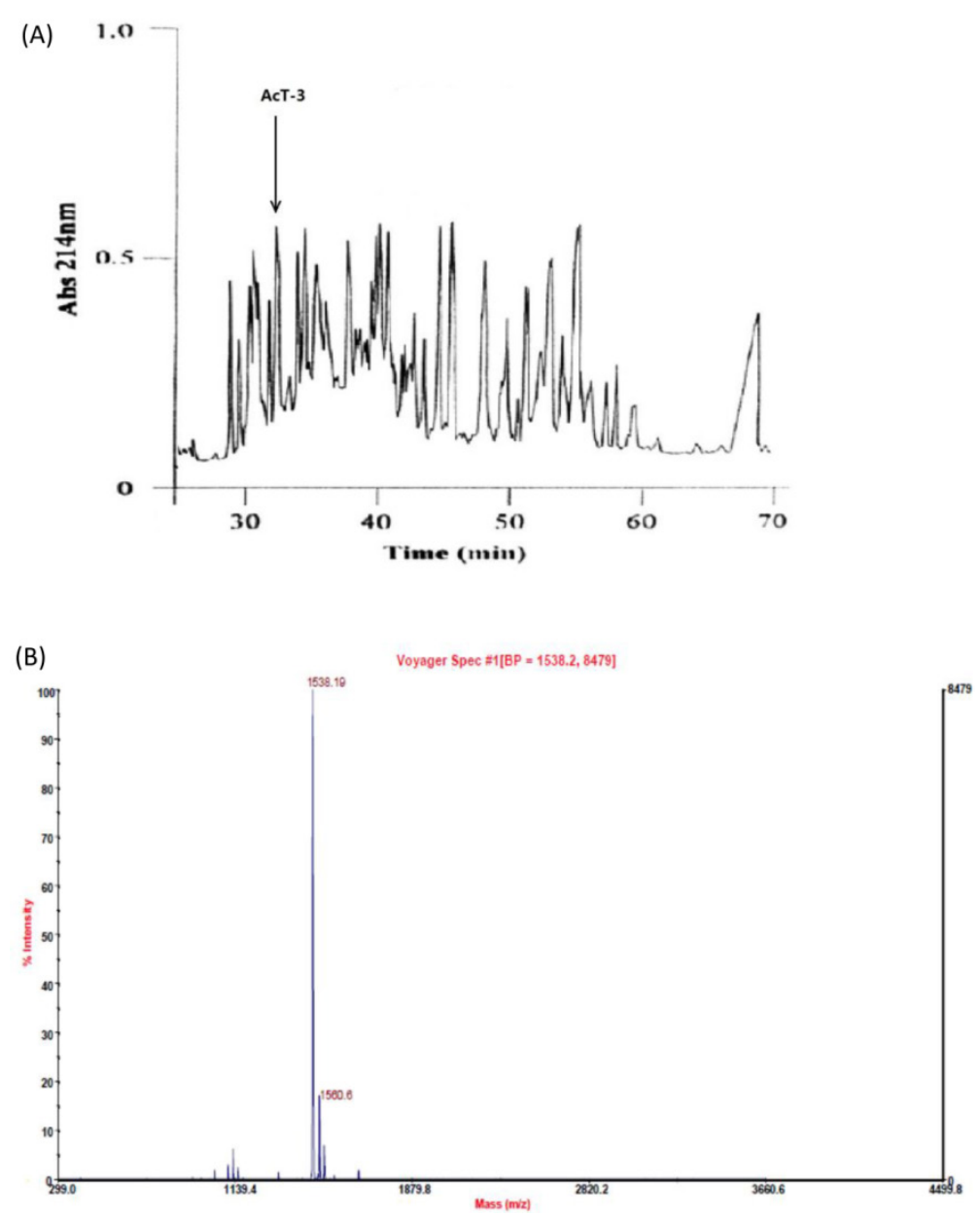

Figure 2. (A) Reversed phase HPLC separation of skin secretion components from Agalychins callidryas. The absorbance was monitored at $214 \mathrm{~nm}$. The retention times of AcT-3 was indicated by arrows. (B)MALDI-TOF mass spectrogram of AcT-3 $(\mathrm{m} / \mathrm{z}=1538.19)$ from a reverse phase HPLC fraction of the frog skin secretion.

\section{The cancer inhibitory activity of AcT-3}

To determine the cancer cell anti-proliferative effects of AcT-3, human prostate cancer cells (LNCap/PC3/DU145), were incubated in a range concentrations of AcT-3 for $72 \mathrm{~h}$. The cell viability was measured by MTT assay. PTX used as a positive control could significantly inhibit all three prostate cancer cell lines. For AcT-3, the inhibitory effect on PC3 cells was more obviously than the other two cell lines. The effect of the peptide on the growth of androgen-dependent prostate cancer LNCaP cells is shown in Fig. 5(A-C). The results suggest that the peptide could inhibit the cells at the highest concentration employed and the inhibitory effect decreased following the time. When the concentration of AcT-3 was $100 \mu \mathrm{M}$, the cell viability of LNCaP cells was $57.66 \% \pm 7.40 \%$ after $24 \mathrm{~h}, 79.69 \% \pm 5.55 \%$ after $48 \mathrm{~h}$ and $79.13 \% \pm 6.67 \%$ after $72 \mathrm{~h}$, compared with the control conditions. Fig.5 (D-F) shows the effect of AcT-3 on the growth of androgen-independent prostate cancer PC3 cells and this peptide could inhibit PC3 cell growth at concentrations from $1 \mu \mathrm{M}$ to $100 \mu \mathrm{M}$. At the optimal anti-growth concentration $(100 \mu \mathrm{M})$, after $24 \mathrm{~h}$, cell viability was $78.53 \% \pm 6.10 \%$; after $48 \mathrm{~h}$, cell viability was $64.06 \% \pm 4.18 \%$; after $72 \mathrm{~h}$, cell viability was $58.73 \% \pm 9.79 \%$, compared to the control conditions. The inhibitory effect increased following the time on this cell line. The anti-proliferative effect of AcT-3 towards human androgen-independent DU145 cells is shown in Fig. 5(G-I). AcT-3 inhibited DU145 cells proliferation at concentrations from $1 \mu \mathrm{M}$ to $100 \mu \mathrm{M}$. Following treatment of DU145 cells with $100 \mu \mathrm{M}$ AcT-3, the cell viability was reduced to $77.45 \% \pm 4.19 \%$ after $24 \mathrm{~h}, 79.56 \% \pm 3.96 \%$ after $48 \mathrm{~h}$ and $80.24 \% \pm 7.94 \%$ after $72 \mathrm{~h}$, compared with the control conditions.

\section{Cell Death ELISA}

To determine the role of cell death in the anti-proliferative process of AcT-3, DNA fragmentation was measured by using the cell death ELISA. The assay carried out at $4 \mathrm{~h}$ was to capture the rapidly-induced process of apoptosis and measured at $16 \mathrm{~h}$ was to get the result of longer-term induction of necrosis.

As shown in Fig. 6, after 4h, DNA fragmentation did not appear to have occurred in any cancer cells as 
no increase in absorbance was observed within the lysates or the supernatants (data not shown). After 16h, DNA fragmentation was observed both in the lysates and the supernatants of all three cell lines. Increased DNA fragments in the cell supernatants were significantly higher than in the cell lysates, which meant that the plasma membrane had been ruptured causing release of the mono- and oligonuclesomes into the cytoplasm. The absorbance of the cell supernatants corresponds to the increase number of dead cells increased with AcT-3 concentrations after 16h, which means that AcT-3 induced prostate cancer cell death through the mechanism of necrosis pathway.

\section{Safety evaluation of AcT-3 by haemolytic assay}

These results demonstrated that AcT-3 showed no lytic activity on horse erythrocytes in the investigated concentrations (Fig. 7), which meant AcT-3 had no obvious cytotoxic effect.
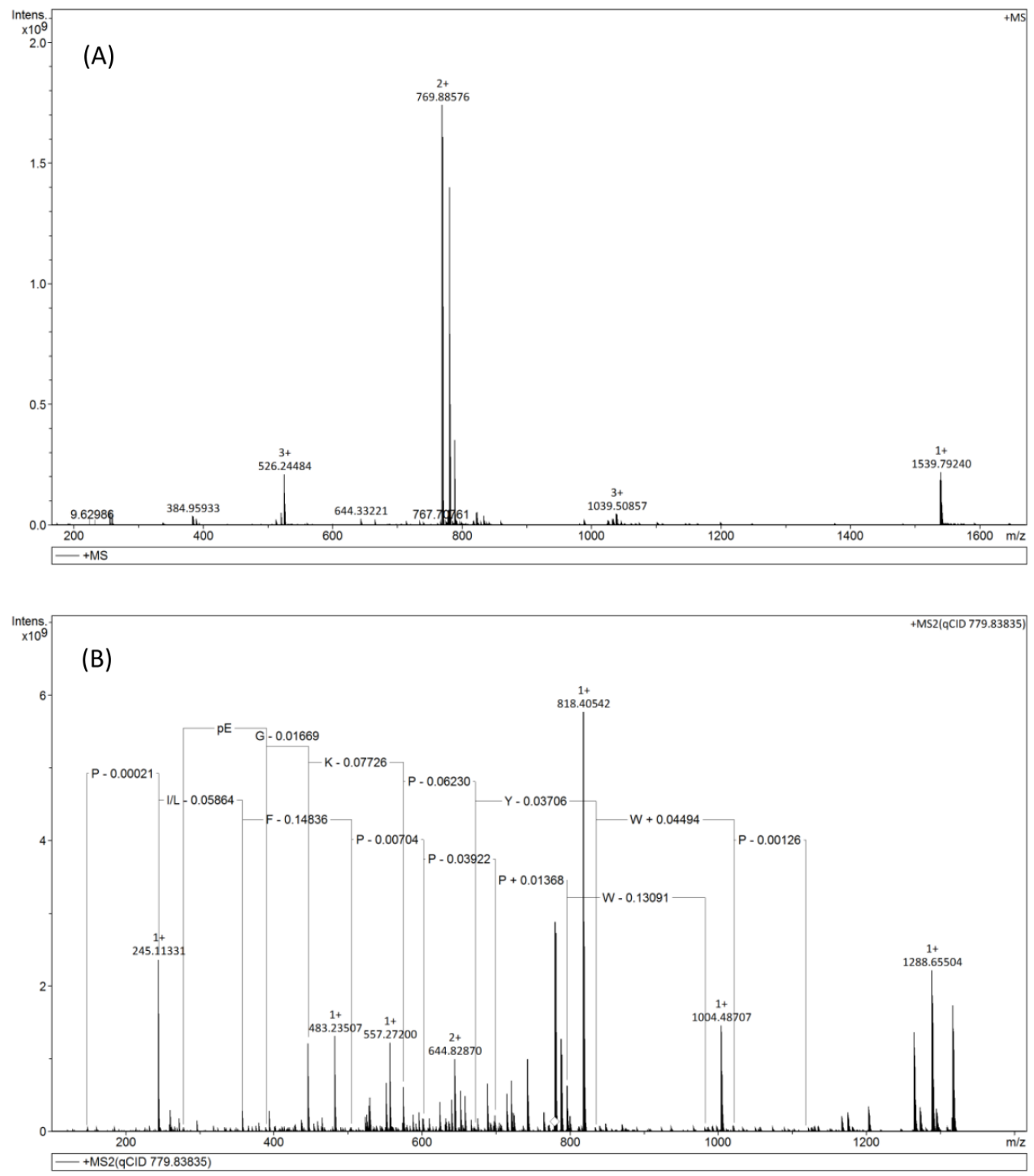

Figure 3. (A) Solarix FT-ICR-MS full scan of AcT-3 from reverse phase HPLC fraction. The doubly charges ion ( $\mathrm{m} / \mathrm{z} 769.88$ ), triply charged ion ( $\mathrm{m} / \mathrm{z} 526.24)$ of a peptide with parent mass of 1539.79Da were detected. (B) MS/MS fragmentation spectrum of doubly charged ion (m/z 769.88). 
(A)

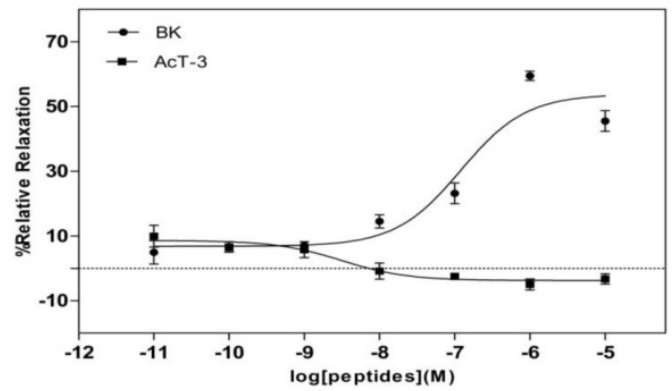

(B)

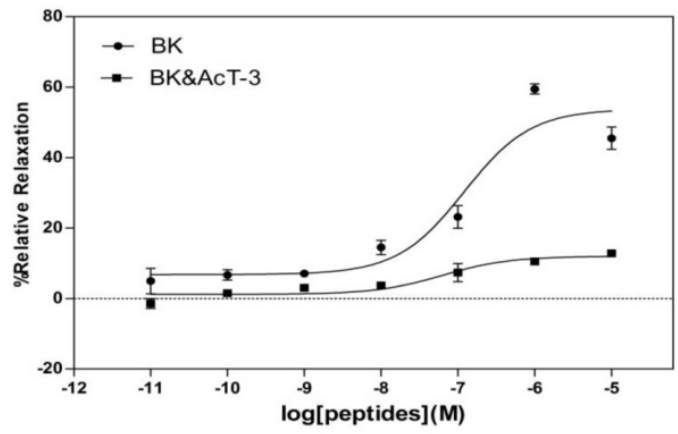

(C)

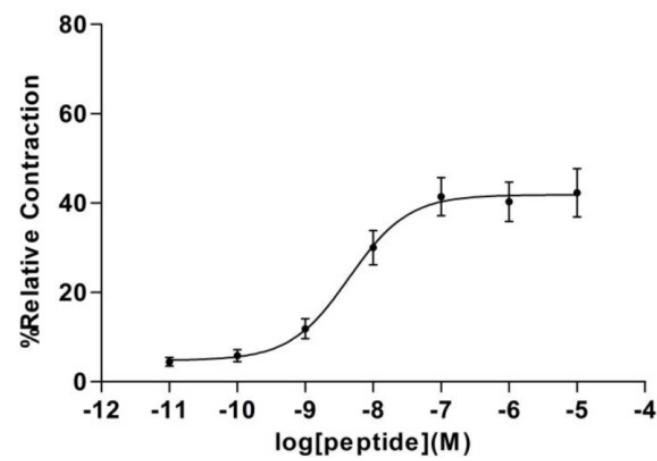

Figure 4. (A) Dose-response curves of Bradykinin $(\bullet)$ and AcT-3 ( $\bullet$ ) in rat tail artery smooth muscle preparations. (B) Dose response of BK in the rat tail artery smooth muscle $(\bullet)$ and BK dose response in AcT-3 pre-incubated (10-6M) artery smooth

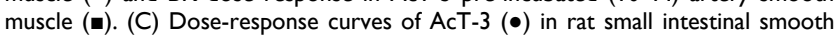
muscle preparations. Error bars indicate the mean \pm SEM. Six replicates of each point were recorded.

\section{Discussion}

Amphibian skin is a rich source of biologically-active compounds that are assumed to have diverse physiological and defence functions. In the range of bioactive peptides, some of have antimicrobial effects against a broad spectrum of bacterial species and others are pharmacologically-active, many of these having endogenous mammalian homologues [23]. To date, many pharmacologically-active peptides have been studied from various species of frogs, especially from the sub-family Phyllomedusinae. The red-eyed leaf frog, Agalychnis callidryas, that was investigated here, also belongs to this frog sub-family and alt- hough this species is readily available in the herpetology pet trade due to its striking beauty and relative ease of captive breeding, few studies have been reported on the compounds isolated from its defensive skin secretions [24]. A preliminary study of Agalychnis species suggested that they contained bioactive peptides which are similar to the peptides identified from other phyllomedusine frogs [13]. Five peptide families have been identified previously in methanol extracts of the skin of $A$. callidryas, namely a caerulein, a phyllokinin, several tachykinins, an opioid peptide and sauvagine [25].

Tryptophyllins are a group of amphibian skin peptides widespread in frogs of the hylid genera, Phyllomedusa and Litoria [14]. This is a group of small peptides, containing four to fourteen amino acid residues, with a common tryptophan (Trp) residue in their structures. They were first identified in and isolated from methanol extracts of Phyllomedusa rohdei skin [26] and since then, a number of TPHs have been discovered from the skins of many hylid species [14]. Two TPHs, PdT-1 (KPHypAWVPV-NH2) and PdT-2 (DMSPPWH-NH2), isolated from the skin of the phyllomedusine frog, Pachymedusa dacnicolor, by Chen et al in 2004, exhibit smooth-muscle activity [24]. A Tryptophyllin type two peptide recently identified from A. callidryas showed myotropic and antimicrobial activities [27]. One of TPHs (FPPWM-NH2) discovered by Erspamer, induces sedation and behavioural sleep in birds and is also immunoreactive to a set of cells in the rat adenohypophysis [13].

Here, a novel TPH peptide, named AcT-3, isolated from skin secretion of A. callidryas, is described. Synthetic replicates of AcT-3 were found to attenuate the bradykinin-induced relaxation response in rat arterial smooth muscle and to contract rat small intestinal smooth muscle preparations. AcT-3 also showed anticancer effect on three types of human prostate cancer lines. The peptide-containing fraction was separated from a complex mixture of peptidic components by reverse-phase HPLC and then analysed by MALDI-TOF mass spectrometry to obtain the molecular mass estimate of 1538.19Da. MS/MS fragmentation of the peptide unequivocally established the primary structure of a proline-rich peptide whose computed molecular mass was very similar to the one obtained by mass spectrometry. The peptide was classified by searching a group of structurally-similar peptides through an NCBI Blast search which revealed that AcT-3 belonged to the T-3 group of the TPH family. 

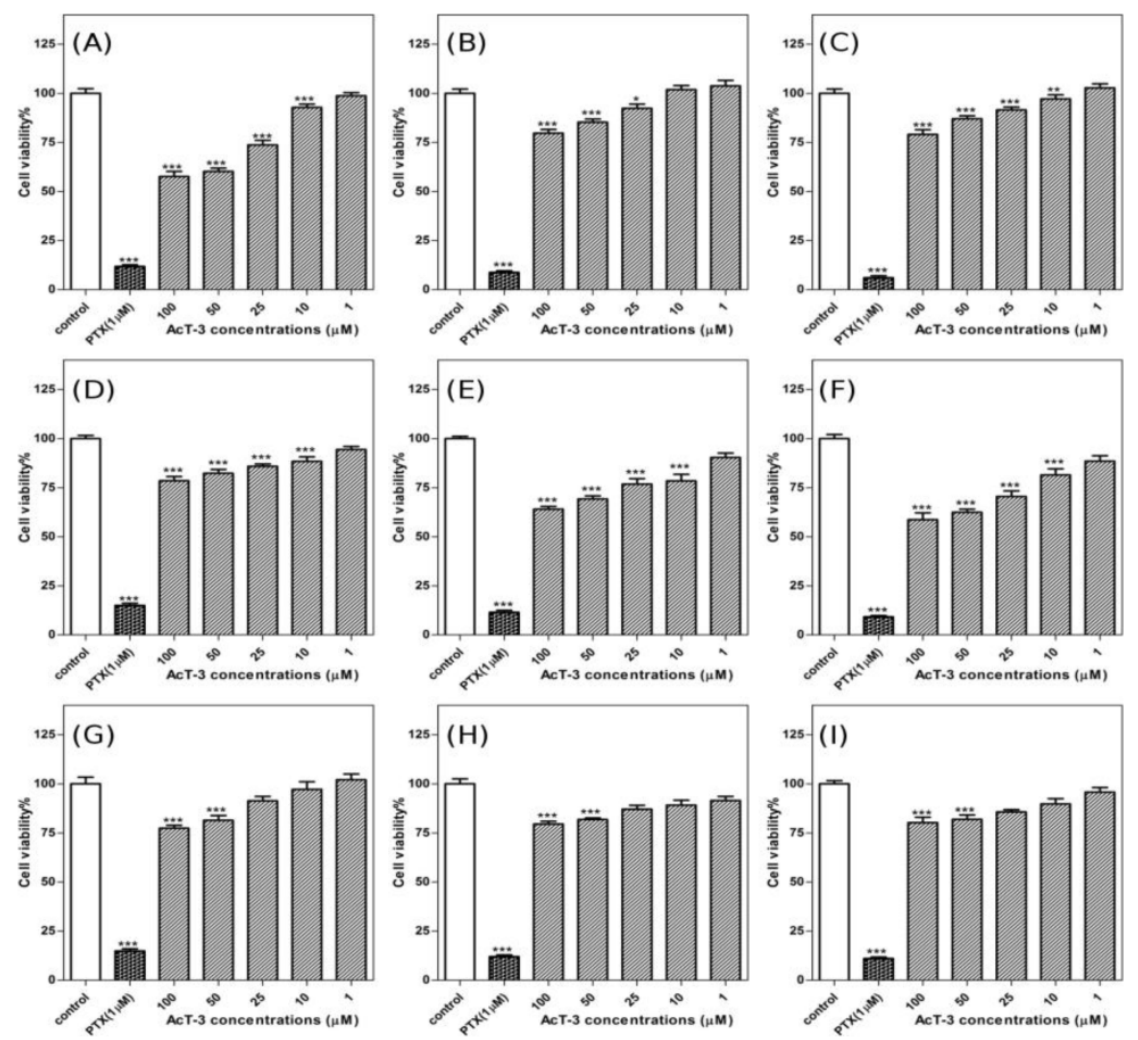

Figure 5. AcT-3 inhibits the proliferation of androgen-dependent prostate cancer LNCaP cells and androgen-independent prostate cancer PC 3 and DU145 cells in $72 \mathrm{~h}$. LNCaP cells were treated with AcT-3 and incubated for $24 \mathrm{~h}(\mathrm{~A}), 48 \mathrm{~h}(\mathrm{~B})$ and $72 \mathrm{~h}(\mathrm{C})$. PC3 cells were treated with AcT-3 and incubated for $24 \mathrm{~h}(\mathrm{D}), 48 \mathrm{~h}(\mathrm{E})$ and $72 \mathrm{~h}(\mathrm{~F})$. DU145 cells were treated with AcT-3 and incubated for $24 \mathrm{~h}(\mathrm{G}), 48 \mathrm{~h}(\mathrm{H})$ and $72 \mathrm{~h}(\mathrm{I})$. Statistical analysis was performed using Student's $t$-test. Data shown represents mean \pm SEM of three separate experiments. Six replicates were recorded in each experiment. Asterisks indicate ${ }^{*} \mathrm{p}<0.05$, ${ }^{* *} \mathrm{p}<0.01$, $* * * \mathrm{p}<0.001$ versus controls.

The presence of this peptide was further confirmed by the fact that it was found to be encoded by a discrete biosynthetic precursor whose structure was deduced from a cDNA that was cloned from a dried skin extract-derived cDNA library of $A$. callidryas. The open-reading frame of AcT-3 exhibited a high degree of similarity with a previously-discovered peptide, PhT-3 from $P$. hypochondrialis. The organisation of the biosynthetic precursor of AcT-3 is typically that observed for many amphibian skin peptides in that it can be generally considered to have four major sequentially-occurring domains. The first encodes a putative signal peptide of 22 amino acid residues that is usually highly-conserved in structure within a given species and often between species [28]. Signal peptides are typical of transcripts encoding products that are destined for secretion. The second encodes another highly-conserved acidic amino acid residue-rich spacer peptide domain whose function is unknown but that possibly plays a role in peptide storage or packaging within secretory cells. This domain consists of a typical propeptide convertase processing site (-RR-) located upstream of the mature active peptide domain and cleavage of this generates the N-terminus of the mature peptide. The third domain encodes the mature peptide and by nature is usually hypervariable in sequence ensuring product diversity from a relatively-conserved biosynthetic precursor template. The fourth domain encodes the C-terminal processing site.

A synthetic replicate of AcT-3 tested in this study was found to antagonise the effect of BK on artery smooth muscle in a manner that suggested a non-competitive mode of action. This effect is likely to extend to other T-3 peptides from other species, especially from the phyllomedusinae sub-family. PhT-3 from $P$. hypochondrialis, is a structural homologue of AcT-3 and exhibits the same pharmacological effect in the rat tail artery.

Prostate cancer is one of the most commonly diagnosed cancers and the second leading cause of cancer deaths in males [31]. In the study of prostate cancer therapeutics, some representative prostate cancer cell lines have been established to investigate prostate cancer in vitro, the most widely used cells are three kinds of cell lines (LNCaP, PC3 and DU145). The PC3 and DU145 cells were isolated from human prostatic adenocarcinoma metastatic to bone and to brain, respectively. The LNCaP cancer cell line was established from a human lymph node metastatic lesion of prostatic adenocarcinoma. LNCaP cells are androgen-dependent prostate cancer cell lines, which 
express the androgen receptor. LNCaP cells will only grow in an androgen-containing environment. In contrast, PC3 and DU145 cells express very little or no AR, so the proliferation of PC3 or DU145 is not androgen dependent $[32,33]$. We choose these cell lines as in vitro prostate cancer model to examine the anticancer effect of AcT-3. Prostate cancer shares with lung cancer a common origin in neuro-endocrine cells. These cells bear receptors for growth factor neuropeptides, such as BK and bombesin. Thereinto, BK has a role to play in the progress of prostate cancer [29] and both BK receptors (B1 and B2) are demonstrated to express in prostate cancer cells [30-31, 34]. The receptors on prostate cancer can bind with growth factor neuropeptides, and effectively stimulate cancer cell growth and production of the congeneric peptides [35]. BK antagonists thus have a great potential to be developed as anticancer drugs. The experimental design used here was to determine the anticancer effect of AcT-3, which has BK antagonism effects in artery smooth muscle. The results showed that AcT-3 treatment, dose-dependently inhibited the proliferation of human prostate cancer cell lines, LNCaP, PC3 and DU145, over $72 \mathrm{~h}$. The antagonism effect on cancer cells is not as obviously as that on smooth muscle, which indicates that the same peptide may have a different binding ability with the same receptor in different tissues. Besides BK, there are many other cancer growth factors like Tyrosine kinases GRB2, EGF and IGF-I [36], so blocking the effect of BK may just partly inhibit cancer cell proliferation. It remains unclear whether AcT-3 acts at one or both of the BK receptors, and thus it cannot be stated indisputably whether antagonism is occurring at the B1 or the B2 receptor, or at both receptors in these cancer cell lines. At last, haemolytic assay is performed as a safety evaluation on the effect of peptides on a standardized model of mammalian cells. Here, we use erythrocytes as a representative to determine the cytotoxic/lytic effects of individual peptides. The results demonstrated that AcT-3 had no observable lytic effects on normal cells.

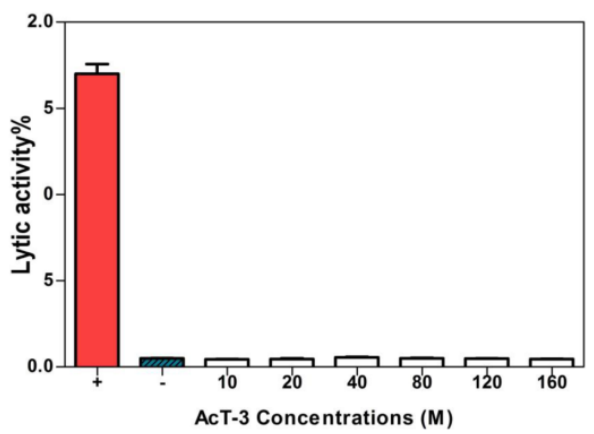

Figure 7. Haemolytic effect of AcT-3. Three replicates at each point were recorded. (Positive control: $2 \%$ red cell suspension + equal volume PBS containing $2 \%$ Triton-100; Negative control: $2 \%$ red cell suspension + equal volume PBS).
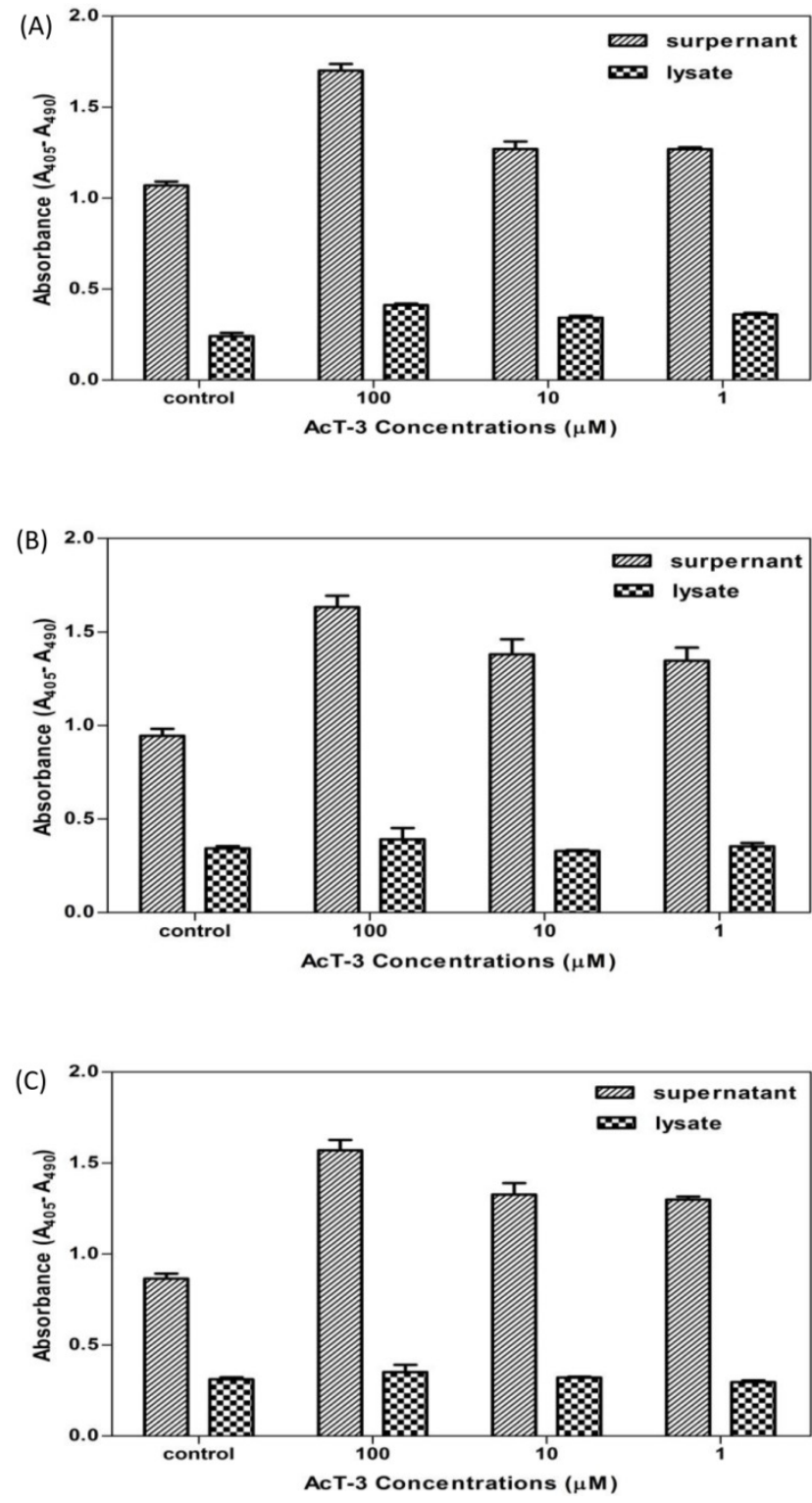

Figure 6. Detection of DNA fragmentation in the cell cytoplasm of human prostate cancer cell lines (A: LNCap; B: PC3; C: DU145) treated with AcT-3. Three replicates at each point were recorded.

\section{Abbreviations}

TPH: tryptophyllin; AcT-3: Agalychnis callidryas tryptophyllin-3 peptide; HPLC: High Performance Liquid Chromatography; MALDI-TOF: Matrix-Assisted Laser Desorption Ionization Time of Flight; FT-ICR-MS: Fouier Transform Ion Cyclotron Resonance Mass Spertrometer; RACE: Rapid Amplification cDNA Ends; BK: Bradykinin; PE: phenylephrine; ELISA: Enzyme-Linked Immune Sorbent Assay; PBS: Phosphate Buffer Solution; TFA: trifluoroacetic acid. 


\section{Acknowledgements:}

This work was supported by a grant from $\mathrm{Na}$ tional Natural Science Foundation of China (No. 81402901), Tianjin Education Commission of China (No. 20120136) and China Postdoctoral Science Foundation (No. 2014M551035).

\section{Author contribution}

TB Chen and C Shaw conceived and designed the experiments, R Wang and Y Zhou Performed the experiment, $\mathrm{R}$ Wang wrote the manuscript, L Wang and $\mathrm{M}$ Zhou coordinated and directed the manuscript writing.

\section{Competing Interests}

The authors have declared that no competing interest exists.

\section{References}

1. Savage JM. The Amphibians and Reptiles of Costa Rica: a herpetofauna between two continents, between two seas. Salt Lake City, United States: University of Chicago Press books. 2002:122-158.

2. Clark BT. The natural history of amphibian skin secretions, their normal function and potential medicinal applications. Biological Reviews of the Cambridge Philosophical Society. 1997; 72: 365-379.

3. Toledo RC and Jared C. Cutaneous granular glands and amphibian venoms. Comparative Biochemistry and Physiology Part A: Physiology. 1995; 111: $1-29$.

4. Elkan E. Mucopolysaccarides in the anuran defence against dessication. Journal of Zoology. 1968; 155: 9-53.

5. Bevins CL and Zasloff M. Peptides from frog skin. Annual Review of Biochemistry. 1990; 59: 395-414.

6. Gomes A, Giri B, Saha A, Mishra R, Dasgupta SC, Debnath A, Gomes A. Bioactive molecules from amphibian skin: their biological activities with reference to therapeutic potentials for possible drug development. Indian J Exp Biol. 2007; 45: 579-593.

7. Li J, Xu X, Xu C, Zhou W, Zhang K, Yu H, Zhang Y, Zheng Y, Rees HH, Lai R, Yang D, Wu J. Anti-infection peptidomics of amphibian skin. Mol Cell Proteomics. 2007; 6: 882-894.

8. Nascimento AC, Fontes W, Sebben A, Castro MS. Antimicrobial peptides from anurans skin secretions. Protein and Peptide Letters. 2003:10: 227-238.

9. VanCompernolle SE, Taylor RJ, Oswald-Richter K, Jiang J, Youree BE, Bowie JH, Tyler MJ, Conlon JM, Wade D, Aiken C, Dermody TS, KewalRamani VN, Rollins-Smith LA, Unutmaz D. Antimicrobial peptides from amphibian skin potently inhibit human immunodeficiency virus infection and transfer of virus from dendritic cells to T cells. J Virol. 2005; 79(18):11598-11606.

10. Chinchar VG, Bryan L, Silphadaung U, Noga E, Wade D, Rollins-Smith L. Inactiviation of viruses infecting ectothermic animals by amphibian piscine antimicrobial peptides. Virology. 2004; 323: 268-275.

11. Apponyi MA, Pukala TL, Brinkworth CS, Maselli VM, Bowie JH, Tyler MJ, Booker GW, Wallace JC, Carver JA, Separovic F, Doyle JR and Llewellyn L. Host-defence peptides of Australian anurans: structure, mechanism of action and evolutionary significance. Peptides. 2004; 25: 1035-1054.

12. Gibson BW, Poulter L, Williams DH, Maggio JE. Novel peptide fragments originating from PGLa and the caerulein and xenopsin precursors from Xenopus laevis. J. Biol. Chem. 1986; 261: 5341-5534.

13. Erspamer V, Melchiorri P, Erspamer FG, Montecucchi PC, De Castiglione R. Phyllomedusa skin, a huge factory and store-house of a variety of active peptides. Peptides. 1985; 6: 7-12.

14. Bowie JH and Tyler MJ. Host defense peptides from Australian amphibians: Caeruliein and other neuropeptides. Handbook of biologically active peptides. 2006; 43: 283-289.

15. Brand GD, Krause FC, Silva LP, Leite JRSA, Melo JAT, Prates MV, Pesquero JB, Santos EL, Nakaie CR, Costa-Neto CM, Bloch C Jr. Bradykinin-related peptides from Phyllomedusa Hypochondrialis. Peptides. 2006; 27: 2137-2146.

16. Erspamer V, Erspamer FG, Cei JM. Active peptides in the skins of two hundred and thirty American amphibian species. Comp Biochem Physiol C. 1986; 85: 125-137.

17. Rates B, Silva LP, Ireno IC, Leite FSF, Borges MH, Bloch C Jr., De Lima ME, Pimenta AM. Peptidomic dissection of the skin secretion of Phasmahyla jandaia. Toxicon. 2011; 57: 35-52.

18. Conlon JM, Jouenne T, Cosette P, Cosquer D, Hubert Vaudry, Christopher K. Abel T, Abel PW. Bradykinin-related peptides and tryptophyllins in the skin secretions of the most primitive extant frog, Ascaphus truei. General and Comparative Endocrinology. 2005; 143: 193-199.

19. Langsdorf M, Ghassempour A, Rompp1 A, Spengler B. Characterization of a peptide family from the skin secretion of the Middle East Tree Frog Hyla savignyi by composition-based de novo sequencing Rapid Commun. Mass Spectrom. 2010; 24: 2885-2899.

20. Chen TB, Walker B, Zhou M, Shaw C. Dermatoxin and phylloxin from the waxy monkey frog, Phyllomedusa sauvagei: Cloning of precursor cDNAs and structural characterization from lyophilized skin secretion. Regulatory Peptides. 2005; 129: 103-108.

21. Ruiz-Carranza PM, Ardila-Robayo MC, Lynch JD. Lista actualizada de la fauna de Amphibia de Colombia. Revista de la Academia Colombiana de Ciencias Exactas. Ficasy Naturales. 1996; 20: 365-415.

22. Amiche M, Ladram A, Nicolas PA. Consistent nomenclature of antimicrobial peptides isolated from frogs of the subfamily Phyllomedusinae. Peptides. 2008; 2: 2074-2082.

23. Barra D, Simmaco M. Amphibian skin: a promising resource for antimicrobial peptides. Trends Biotechnol. 1995; 13: 205-209.

24. Wang L, Zhou M, Chen T, Walker B, Shaw C. PdT-2: A novel myotropic Type-2 tryptophyllin from the skin secretion of the Mexican giant leaf frog, Pachymedusa dacnicolor. Peptides. 2009; 30: 1557-1561.

25. Mignogna G, Pascarella S, Wechselberger C, Hinterleitner C, Mollay C, Amiconi G, Barra D, Kreil G. BSTI, a trypsin inhibitor from skin secretions of Bombina bombina related to protease inhibitors of nematodes. Protein Sci. 1996; 5: 357-362.

26. Montecucchi PC. Isolation and primary structure determination of amphibian skin tryptophyllins. Peptides. 1985; 6: 187-195.

27. Ge L, Lyu P, Zhou M, Zhang H, Wang Y, Li B, Li R, Chen T, Shaw C. AcT-2: a novel myotropic and antimicrobial type 2 tryptophyllin from the skin secretion of the Central American red-eyed leaf frog, Agalychnis callidryas. ScientificWorldJournal. 2014; 2014: 176214.

28. Vanhoye D, Bruston F, Nicolas P, Amiche M. Antimicrobial peptides from hylid and ranin frogs originated from a 150-million-year-old ancestral precursor with a conserved signal peptide but a hypermutable antimicrobial domain. Eur.J. Biochem. 2003; 70: 2068-2081.

29. Papandreou CN, Usmani B, Geng YP, Bogenrieder T, Freeman R, Wilk S, Finstad CL, Reuter VE, Powell CT, Scheinberg D, Magill C, Scher HI, Albino AP, Nanus DM. Neutral endopeptidase 24.11 loss in metastatic human prostate cancer contributes to androgen-independent progression. Nat Med. 1998; 4: 50-57.

30. Srinivasan D, Burbach LR, Daniels DV, Ford W, Bhattacharya A. Pharmacological characterization of canine bradykinin receptors in prostatic culture and in isolated prostate. Br J Pharmacol. 2004; 142: 297-304.

31. Taub JS, Guo R, Leeb-Lundberg LMF, Madden JF, Daaka Y. Bradykinin Receptor Subtype 1 Expression and Function in Prostate Cancer. Cancer research. 2003; 63: 2037-2041.

32. Kokontis JM, Hsu S, Chuu CP, Dang M, Fukuchi J, Hiipakka RA, Liao S. Role of androgen receptor in the progression of human prostate tumor cells to androgen independence and insensitivity. The Prostate. 2005; 65: 287-298.

33. Umekita Y, Hiipakka RA, Kokontis JM, Liao S. "Human prostate tumor growth in athymic mice: inhibition by androgens and stimulation by finasteride". Proc. Natl. Acad. Sci. U.S.A. 1996; 93: 11802-11807.

34. Barki-Harrington L, Bookout AL, Wang GF, Lamb ME, Leeb-Lundberg LM, Daaka Y. Requirement for direct cross-talk between B1 and B2 kinin receptors for the proliferation of androgen-insensitive prostate cancer PC3 cells. Biochem. J. 2003; 371:581-587.

35. Stewart JM, Gera L, Chan DC, Bunn Jr PA, York EJ, Simkeviciene V, Helfrich B. Bradykinin-related compounds as new drugs for cancer andinflammation. Can J Physiol Pharm. 2002; 80: 275- 280.

36. Rajkumar T. Growth factors and growth factor receptors in cancer. Current science. 2001; 8: 535-541. 